\title{
KONSEP MAT DALAM MUSIK KULINTANG TARI MILUR
}

\author{
Dedy Firmansyah ${ }^{1}$, Awang Kautzar ${ }^{2}$ \\ Universitas PGRI Palembang ${ }^{1}$ \\ firmansyahdedy321@gmail.com ${ }^{1}$ \\ Universitas PGRI Palembang ${ }^{2}$ \\ angindiawan@gmail.com ${ }^{2}$
}

\begin{abstract}
Abstrak
Fungsi musik kulintang bagi masyarakat suku komering ialah sebagai sarana pendukung untuk melangsungkan seluruh proses pernikahan adat suku Komering. Salah satu proses pernikahan tersebut di dalamnya terdapat prosesi menggunakan tari milur yang diiringi oleh musik kulintang. Konsep mat merupakan karakter khas sekaligus pedoman dalam permainan musik kulintang, sehingga penulis tertarik untuk mengkaji konsep mat dalam musik kulintang suku komering, khususnya dalam mengiringi tari milur. Penelitian ini juga melakukan analisis bentuk dan struktur konsep mat musik kulintang dalam tahapan pernikahan suku Komering khususnya dalam mengiringi tari milur. Analisis meliputi unsur-unsur musikal yang terdapat dalam bentuk dan struktur penyajian musiknya seperti frase, figure dan motif. Penelitian ini menggunakan metode kualitatif dan pengumpulan data dilakukan dengan cara observasi, wawancara, studi data tertulis dan dokumen. Hasil penelitian ini menyimpulkan bahwa konsep mat dalam musik kulintang untuk mengiringi tari milur adalah suatu pedoman koordinasi permainan musik agar setiap pemain dapat memainkan instrumen musiknya dengan benar dan tepat. Sedangkan bentuk musik kulintang dalam mengiringi tari milur selalu diawali dengan konsep mat di setiap pertunjukannya.
\end{abstract}

Kata kunci: adat pernikahan; bentuk musik; kulintang; mat

\begin{abstract}
The function of kulintang music for the Komering tribe is as a supporting means to carry out the entire process of customary marriage of the Komering tribe. One of the marriage process in it there is a procession using milur dance accompanied by kulintang music. The concept of mat is a distinctive character as well as a guideline in the kulintang music game, so the writer is interested in studying the concept of mat in the komering kulintang music, especially in accompanying the milur dance. This study also analyzes the shape and structure of the kulintang music mat concept in the stages of the Komering marriage, especially in accompanying the milur dance. The analysis includes musical elements contained in the form and structure of the musical presentation such as phrases, figures and motifs. This study uses qualitative methods and data collection is done by observation, interviews, study of written data and documents. The results of this study conclude that the concept of mat in kulintang music to accompany the milur dance is a guideline for coordinating musical games so that each player can play his musical instruments correctly and appropriately. Whereas the form of kulintang music in accompanying the milur dance always begins with the concept of mat in each of its performances.
\end{abstract}

Keywords: customary marriage; music form; kulintang; mat

\section{Pendahuluan}

Musik kulintang di Kabupaten OKU Timur merupakan salah satu kesenian musik yang dimiliki suku Komering. Alat musik kulintang menjadi bagian yang tak terpisahkan dari kehidupan masyarakat suku Komering karena sebagai sarana yang mutlak diperlukan dalam upacara ritual adatnya yaitu pernikahan. Setidaknya terdapat empat upacara yang 
menggunakan musik kulintang sebagai iringannya yaitu pada saat acara arak-arakan (menjemput pengantin), tarian milur, tarian sada sabai, dan pemberian gelar. Bagi suku Komering di OKU Timur, musik kulintang sudah merupakan satu kesatuan dalam setiap tahapan proses adat pernikahan sukunya, sehingga dapat dikatakan bahwa musik kulintang tergolong musik etnik (Sasongko, 2019, p. 34). Bentuk musik kulintang dapat dilihat pada gambar 1.

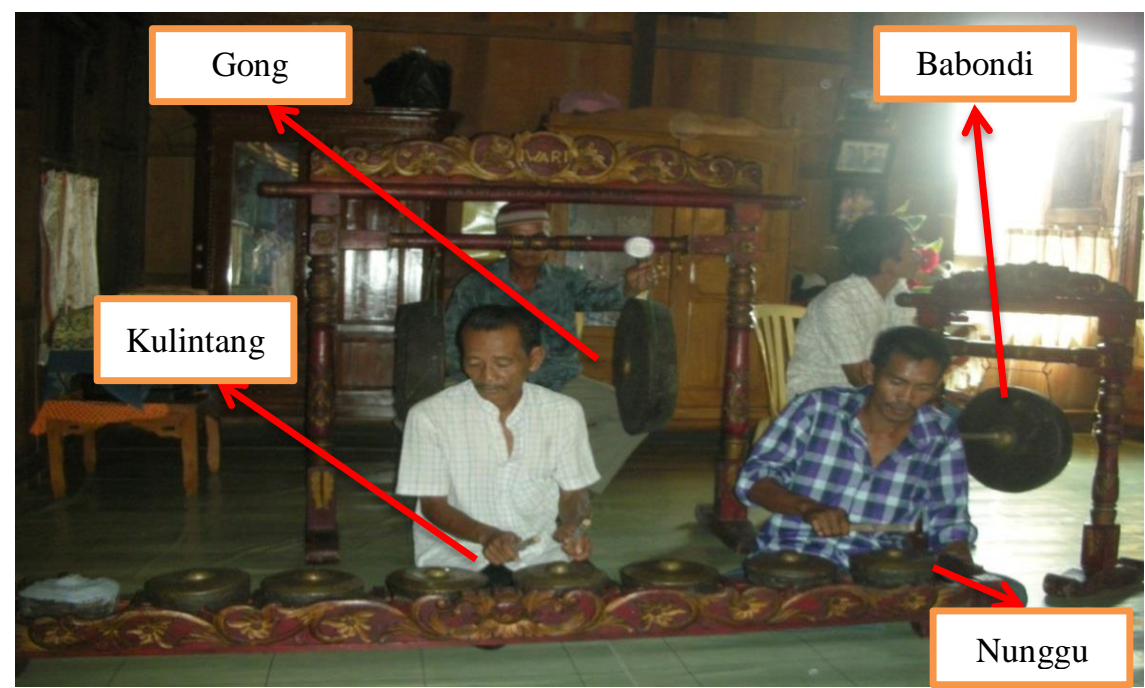

Gambar 1. Seperangkat Alat Musik Kulintang

(Dokumentasi: Firmansyah)

Alat musik inti pada kulintang terdiri dari delapan buah pencon logam berukuran kecil yang disusun secara horizontal dan sejajar, lalu diletakkan di atas sebuah stand yang terbuat dari kayu. Dalam proses penyajiannya alat musik inti kulintang tersebut dibantu oleh alat musik lain yang berbentuk pencon logam berukuran sedang dan besar, sedangkan pencon logam berukuran sedang disebut babondi atau tawak-tawak dengan jumlah satu buah. Pencon logam berukuran besar disebut tala atau gong dengan jumlah satu buah. Dapat dilihat pada gambar 1 bahwa musik kulintang merupakan seperangkat dari seluruh kesatuan beberapa alat musik tersebut.

Musik kulintang suku Komering dimainkan dengan cara dipukul menggunakan kayu dan membutuhkan empat orang untuk memainkannya yang terdiri dari dua orang memainkan delapan buah pencon logam kecil (kulintang), seorang memainkan pencon logam sedang (tawak-tawak atau babondi) dan seorang lagi memainkan sepasang pencon logam besar (gong). Dua orang yang memainkan delapan buah pencon kecil berbagi peran, dimana seorang sebagai pemain melodi sedangkan yang seorang lagi berperan sebagai penjaga tempo atau dalam istilah permainan ini disebut nunggu. 
Istilah mat dalam permainan musik kulintang merupakan suatu aba-aba yang dimainkan oleh salah satu pemain kulintang untuk mengundang pemain lain masuk dan bergabung dalam suatu permainan kulintang. Sistem mat terdapat di 3 permainan musik kulintang yaitu saat mengiringi arak-arakan, mengiringi tari milur, dan mengiringi tari sada sabai. Konsep mat sangat penting untuk diketahui karena selalu menjadi patokan dalam memulai permainan musik kulintang. Oleh karena konsep mat menjadi bagian dalam bentuk musik kulintang yang tidak terlepas dari struktur yang membangunnya, sehingga untuk mengkajinya perlu mengidentifikasi dan mengklasifikasi keseluruhan struktur yang terdapat dalam musik kulintang.

Analisis bentuk sebuah musik menurut Leon Stein adalah mengklasifikasikan unsur-unsur musikal atau struktur yang membangun bentuk musik tersebut. Klasifikasi struktur terhadap sebuah bentuk musik dimulai dari struktur terbesar yaitu frase atau kalimat lagu, kemudian struktur yang lebih kecil yaitu motif, hingga struktur terkecil yang masih dapat diidentifikasi yaitu figure (Stein, 1979). Proses analisis ini berlaku secara general terhadap semua bentuk musik karena pada dasarnya bunyi yang dihasilkan sebuah musik tentunya mengandung melodi dan ritme.

Analisis bentuk musik kulintang pada tulisan ini menggunakan disiplin ilmu musikologi, meskipun nada-nada di dalamnya tidak dapat merepresentasikan frekuensi secara tepat. Hal ini dilakukan dengan pertimbangan untuk dapat memudahkan pembaca dalam mengetahui melodi dan dapat menjadi salah satu bentuk pendokumentasian permainan kulintang. Dengan penulisan not balok yang bersifat universal ini juga akan membuat identifikasi serta proses pengklasifikasian bentuk dan struktur menjadi lebih mudah dipahami.

\section{Metode Penelitian}

Untuk mendapatkan hasil penelitian yang sesuai dengan tujuan yaitu mengenai konsep mat musik kulintang, maka diperlukan metode penelitian yang bersifat kualitatif. Penelitian kualitatif merupakan sebuah bidang penelitian yang berdiri sendiri. Penelitian kualitatif menerobos disiplin, bidang, dan pokok bahasan (Denzin \& Lincoln, 2011, p. 2). Pernyataan tersebut sejalan dengan penelitian ini yang tidak hanya mengkaji kulintang dari sudut pandang musiknya saja, namun juga aspek sosial seperti eksistensi musik kulintang tersebut dalam adat pernikahan suku Komering di Kabupaten OKU Timur. 
Teknik pengumpulan data pada penelitian ini menggunakan observasi, wawancara, dan studi dokumen. Penulis melakukan observasi terlibat di daerah kabupaten OKU Timur Sumatera Selatan khususnya dalam adat pernikahan suku Komering yang dilakukan oleh empat marga yang masih memiliki alat musik kulintang. Sedangkan wawancara dilakukan kepada beberapa responden di tempat penelitian seperti Muhammad Yakub Marga Semendawai Suku III selaku pemangku adat Marga Semendawai Suku III dan Fahmi tokoh adat Marga Paku Sengkunyit, serta beberapa seniman kulintang.

Dari segi fungsi dan kedudukannya, dokumen dibedakan menjadi dua macam yaitu a) dokumen formal, dokumen yang dikeluarkan oleh lembaga tertentu, dan b) dokumen informal, dokumen yang semata-mata merupakan catatan pribadi seperti buku harian dan catatan-catatan pribadi (Ratna, 2010, p. 234). Dokumen formal diperoleh dari beberapa lembaga seperti dinas kebudayaan dan pariwisata OKU Timur, Lembaga Adat, sedangkan dokumen informal didapatkan dari dokumentasi masyarakat tentang alat musik kulintang berupa tulisan dan foto.

\section{Tari Milur}

Istilah milur dalam bahasa Komering berarti saudara mempelai laki-laki yang telah bersuami. Para pelaku tari milur ialah saudara perempuan dari mempelai pria yang telah bersuami baik itu adik, kakak, maupun sepupu. Tari milur bermakna selamat datang dari keluarga mempelai pria kepada mempelai wanita yang kini telah resmi menjadi bagian dari keluarganya. Proses tari milur dilaksanakan pada saat rombongan arak-arakan telah sampai di depan gerbang rumah mempelai pria, dan kedua mempelai disambut dengan tari milur. Bentuk tari milur pada tahun 1984 dapat dilihat pada gambar 2.

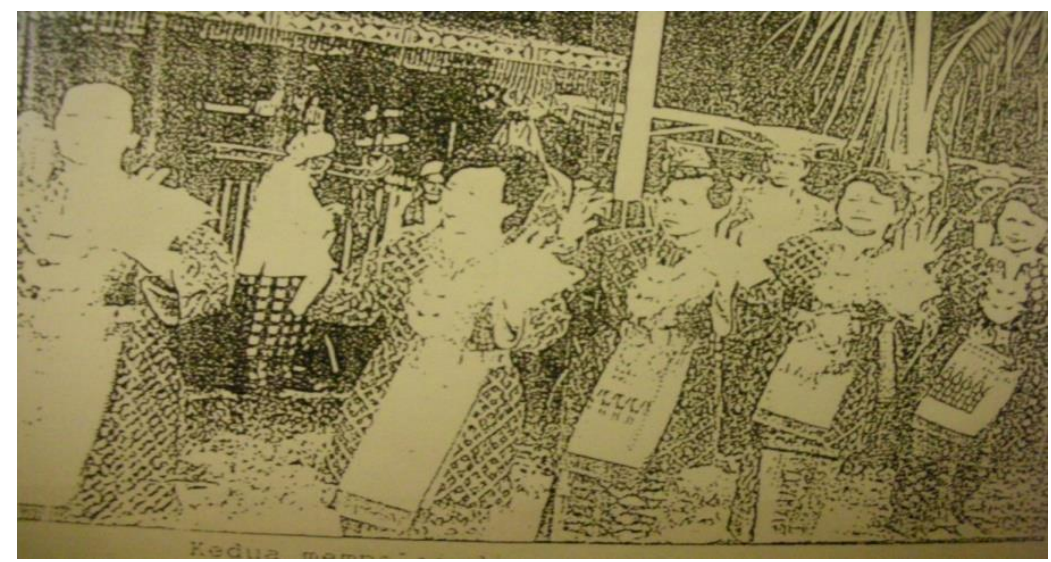

Gambar 2. Tari Milur Menyambut Kedua Mempelai Tahun 1984 (Repro, Firmansyah 2014) 
Tari milur dalam pelaksanaannya menggunakan sarana musik kulintang. Tari milur terdapat dalam adat pernikahan suku Komering di Marga Semendaway Suku III. Namun karena aktivitas berkesenian musik kulintang dan apresiasi masyarakat yang rendah terhadap adat pernikahan suku Komering di marga tersebut, maka saat ini tari milur sudah sulit dijumpai lagi dalam proses adat pernikahan di OKU Timur. Bentuk pertunjukan musik kulintang dalam mengiringi tari milur pada tahun 1984 dapat dilihat pada gambar 3.

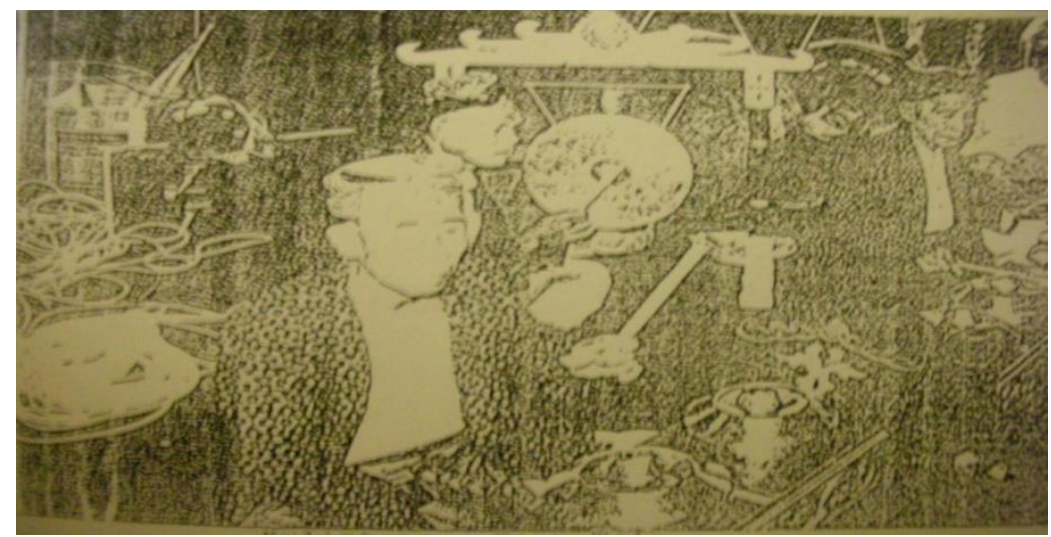

Gambar 3. Pemain Kulintang Mengiringi Tari Milur Tahun 1984 (Repro, Firmansyah 2014)

\section{Konsep Mat dalam Musik Kulintang Tari Milur}

Penyajian musik kulintang untuk tari milur mempunyai banyak kesamaan di setiap sanggar kulintang yang terdapat di OKU Timur, baik dalam bentuk permainan maupun koordinasi antar instrumen. Dari semua desa yang mempunyai sanggar kulintang, semua seniman sepakat menyatakan bahwa melodi kulintang tidak dapat dimainkan tanpa pemain nunggu, pemain babondi, serta pemain gong. Dengan demikian ansambel musik kulintang tidak dapat dimainkan oleh pemain tanpa mendengar instrumen yang memberikan aba-aba awal. Adanya koordinasi dan saling ketergantungan antar instrumen agar permainan kulintang dapat berjalan dengan baik. Sistem koordinasi permainan dengan menunggu abaaba masuk dari instrumen lain ini dikenal oleh seniman kulintang dengan istilah mat.

Mat ini diawali dengan permainan salah satu instrumen yang memberikan tempo untuk memberikan aba-aba masuk kepada instrumen lain. Setelah mendapatkan aba-aba masuk, maka pemain instrumen lain membuat pola tabuhan awal untuk memberikan abaaba masuk juga bagi pemain instrumen lain. Setelah semua instrumen ikut bermain, maka seluruh permainan musik kulintang mulai berjalan beriringan.

Peranan gong dalam permainan musik kulintang ialah memberikan sebuah ruang sekaligus batasan frase bagi pemain kulintang untuk mengisinya dengan sebuah pola 
tabuhan melodi. Satu frase permainan musik kulintang ditandai dengan dua kali bunyi pukulan gong. Setelah dua kali bunyi gong yang menandai berakhirnya satu frase maka pada frase selanjutnya alat musik kulintang membuat rangkaian melodi lagi dan begitu seterusnya hingga proses ritual adat selesai.

\section{Analisis Konsep Mat dan Struktur Musik pada Tari Milur}

Musik kulintang dalam tarian milur memang permainannya tidak fleksibel seperti musik arak-arakan, dikarenakan musik kulintang dalam tarian milur haruslah selaras dengan tariannya sehingga satu frase harus mencapai tempo yang tepat dengan gerakan penarinya. Akan tetapi terdapat kesamaan konsep bentuk dan struktur musik antara tari milur dan musik arak-arakan. Salah satu kesamaannya ialah satu frase bentuk musiknya mempunyai jumlah yang sama yaitu dua birama. Identifikasi mengenai struktur motif, figure, dan frase pada tari milur ditulis sebanyak dua birama dikarenakan birama-birama selanjutnya merupakan repetisi dan variasi.

Permainan musik kulintang tari milur diawali dengan permainan instrumen nunggu selama satu pola figure sebanyak satu birama yang bertujuan memberikan aba-aba kepada instrumen babondi. Permainan pola figure yang dimainkan oleh instrumen nunggu dilakukan secara berulang-ulang, baik nada dan ritme di setiap birama. Pola figure yang dimainkan instrumen nunggu sebanyak satu frase (dua birama) dapat dilihat pada partitur 1.

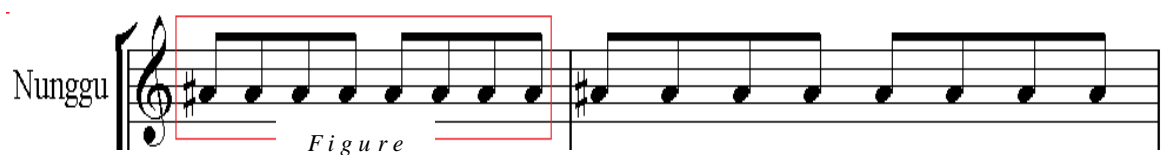

Partitur 1. Figure dan Frase Pola Tabuhan Nunggu dalam Tari Milur (Sumber: Versi Sanggar Kulintang Munggah Jaman)

Setelah instrumen babondi menerima aba-aba dari instrumen nunggu, maka instrumen babondi juga akan memainkan satu pola figure sebanyak satu birama. Satu birama yang dimainkan oleh babondi ini bertujuan untuk mengajak instrumen gong dan kulintang memulai permainan bersama-sama yang dapat dilihat pada partitur 2 . 


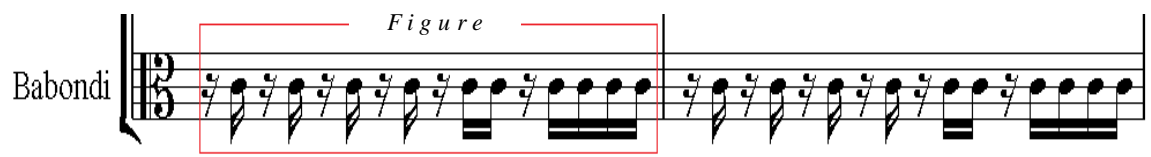

Partitur 2. Figure dan Frase Pola Tabuhan Babondi dalam Tari Milur (Sumber: Sanggar Kulintang Munggah Jaman)

Permainan kulintang dimulai setelah menerima aba-aba sebuah pola figure dari instrumen nunggu selama dua birama dan instrumen babondi selama satu birama. Musik kulintang dimainkan dengan struktur motif melodi dan ritme menggunakan tangan kiri dan tangan kanan yang dapat dilihat pada partitur 3. Satu frase dari permainan musik kulintang terdiri dari dua birama. Motif-motif kalimat lagu dari permainan kulintang baik melodi maupun ritme merupakan sebuah hasil kreativitas dari seniman.

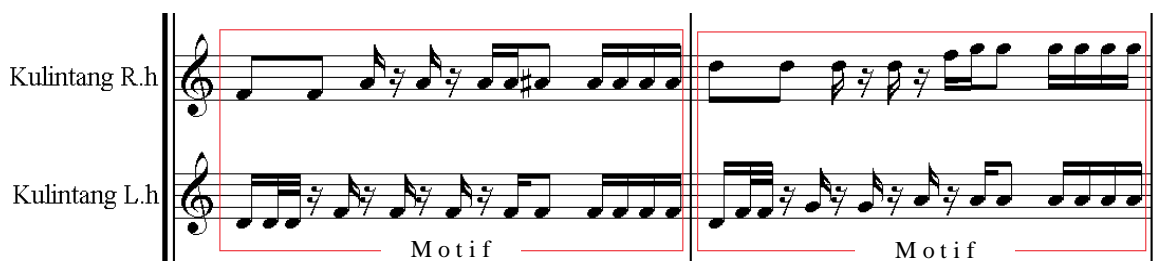

Partitur 3. Motif dan Frase Pola Tabuhan Melodi dalam Tari Milur (Sumber: Sanggar Kulintang Munggah Jaman)

Aba-aba permainan untuk dimulainya instrumen gong bersamaan dengan instrumen kulintang yaitu setelah instrumen nunggu memainkan pola figure selama dua birama dan instrumen babondi selama satu birama. Permainan gong juga memiliki pola figure yaitu nada empat ketuk yang dimulai disetiap awal birama. Instrumen gong dalam permainan musik kulintang mempunyai fungsi sebagai penanda suatu frase. Satu kalimat lagu terjadi setelah gong berbunyi dua kali, dan bunyi gong berikutnya sudah merupakan frase baru. Permainan satu frase dari musik kulintang berpedoman pada instrumen gong yang dibunyikan sebanyak dua kali tersebut dan dapat dilihat pada partitur 4.

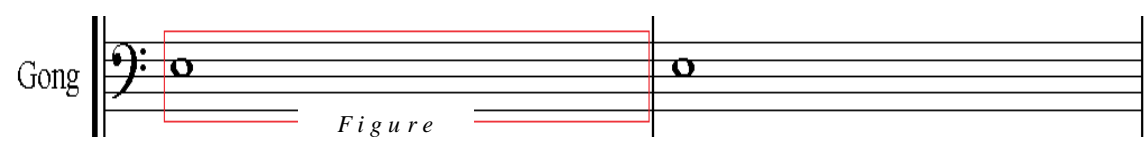

Partitur 4. Figure dan Frase Pola Tabuhan Gong dalam Tari Milur (Sumber: versi sanggar kulintang munggah jaman)

Penjelasan yang sudah diberikan sebelumnya menunjukkan bahwa terdapat sistem aba-aba dalam bentuk permainan musik kulintang untuk mengiringi tari milur. Mat dalam permainan musik kulintang tari milur digunakan hanya pada awal permainan. Akan tetapi 
konsep mat dalam permainan musik kulintang tari milur memiliki perbedaan dengan musik kulintang pada proses arak-arakan. Konsep mat musik kulintang pada proses arak-arakan dimulai oleh melodi kulintang, sedangkan pada tari milur diawali oleh instrumen nunggu. Konsep mat dalam permainan musik kulintang untuk mengiringi proses tari milur yang dapat dilihat di partitur 5 .

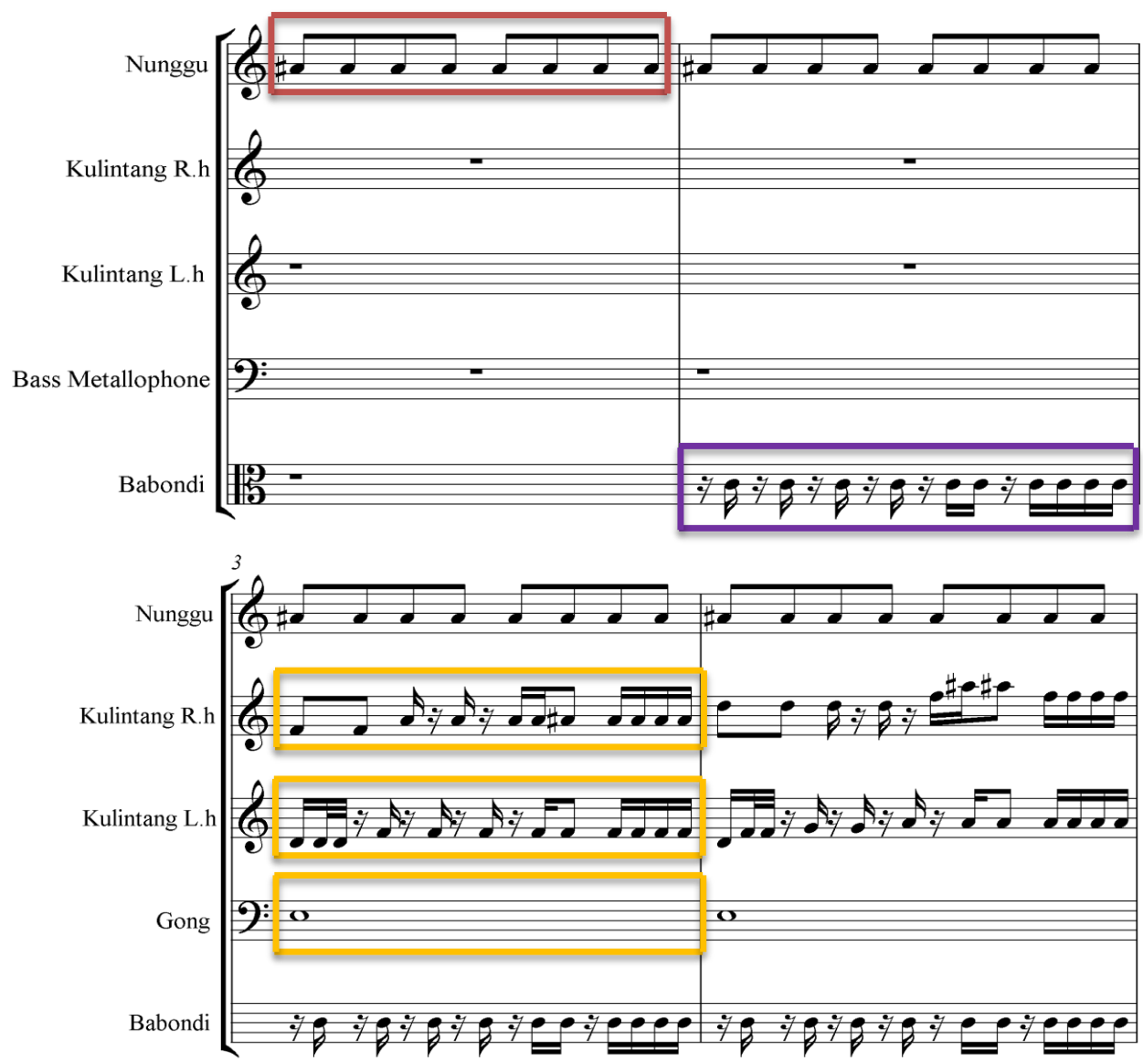

Partitur 5. Konsep Mat dalam Musik Kulintang Tari Milur

(Sumber: Sanggar Kulintang Munggah Jaman)

Keterangan:

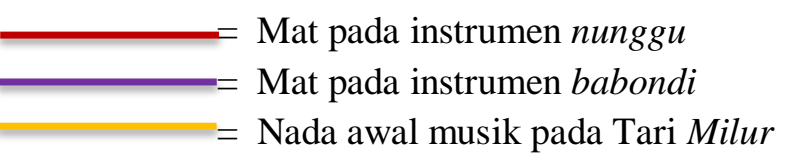

Pada partitur 5 dapat dilihat bahwa konsep mat musik kulintang dalam tari milur diawali dengan instrumen nunggu selama 1 birama, lalu dilanjutkan dengan permainan mat pada instrumen babondi selama 1 birama dan pada akhirnya permainan mat dimainkan oleh instrumen kulintang dan gong secara bersamaan selama 1 birama. Dalam permainan musik kulintang pada tari milur, frase instrumen babondi, nunggu, dan gong dimainkan 
berulang-ulang tanpa perubahan ritme dan melodi hingga selesainya penyajian tari milur. Bunyi mat dalam musik kulintang untuk mengiringi tari milur sama pentingnya dengan bunyi awal saxophone pada penyajian Tanjidor dalam iringan Midang yaitu sebagai instruksi dimulainya sebuah permainan musik (Heryanto, 2015, p. 176). Sehingga dapat disimpulkan bahwa konsep mat dalam musik kulintang memiliki peranan penting sebagai media komunikasi antar pemain di setiap pertunjukan yang dilakukan.

\section{Kesimpulan}

Musik kulintang bagi suku Komering di OKU Timur merupakan satu kesatuan yang tidak dapat dipisahkan dalam setiap tahapan proses adat pernikahan sukunya. Pernikahan tersebut terdiri dari empat upacara yang menggunakan musik kulintang sebagai iringannya yaitu pada saat acara arak-arakan (jemput pengantin), tarian milur, tarian sada sabai, dan pemberian gelar. Fungsi musik kulintang dalam tari milur adalah untuk menyambut kedatangan mempelai wanita ke rumah keluarga besar mempelai pria dalam proses pernikahan dan penyajian tarian berlangsung sekitar 10 menit.

Pertunjukan musik kulintang dalam mengiringi proses adat pernikahan memiliki konsep permainan yang unik dan menarik yaitu mat. Konsep mat ini menjadi bagian penting dalam sistem komunikasi antar pemain supaya dapat menghasilkan pertunjukan musik kulintang yang padu dan kompak. Sistem koordinasi antar pemain dalam memainkan masing-masing instrumen musiknya untuk mengiringi tari milur dimulai dengan tidak berbarengan karena menggunakan mat. Konsep mat dalam musik kulintang untuk mengiringi tari milur dimulai dari instrumen nunggu, lalu babondi, lalu kulintang dan gong secara bersamaan. Masing-masing instrumen tersebut memainkan konsep mat selama 1 birama.

\section{Kepustakaan}

Denzin, N. K., \& Lincoln, Y. S. (2011). The Sage Handbook Qualitative Research 1. Yogyakarta: Pustaka Pelajar.

Heryanto. (2015). Perubahan Bentuk Sajian Midang pada Masyarakat Morgesiwe Kacamatan Kayuagung Kabupaten Ogan Komering Ilir. Gelar: Jurnal Seni Budaya, 13(2), 168-177. Retrieved from http://jurnal.isiska.ac.id/index.php/gelar/article/view/1643/1583

Ratna, N. K. (2010). Metodologi Penelitian Kajian Budaya dan Ilmu sosial Humaniora Pada Umumnya. Yogyakarta: Pustaka Pelajar. 
Sasongko, M. H. (2019). Musik Etnik Dan Pengembangan Musik Gereja. Tonika: Jurnal Penelitian Dan Pengkajian Seni, 2(1), 32-47. Retrieved from http://journal.sttabdiel.ac.id/tonika/article/view/41

Stein, L. (1979). Structure and Style The Study and Analysis of Musical Form. Miami: Summy - Birchard Music. 